\title{
EMOTIONAL AND HABITUAL OVEREATING AND DIETARY RESTRICTIONS IN THE EATING HABITS OF GIRLS AND BOYS
}

\author{
Barbara Janota , Martyna Czapla², Marika Wlazło², Elżbieta Szczepańska ${ }^{1}$ \\ ${ }^{1}$ Department of Human Nutrition, School of Health Sciences in Bytom, Medical University of Silesia in \\ Katowice, Poland \\ ${ }^{2}$ Scientific Society of Young Educators, Department of Human Nutrition, School of Health Sciences in \\ Bytom, Medical University of Silesia in Katowice, Poland
}

\begin{abstract}
Background. Eating habits are mainly shaped at the first stages of human life. Incorrect eating habits in young individuals may in the future lead to eating disorders and predispose to abnormal body weight.

Objective. The aim of the study was to investigate eating habits among adolescents and verify whether there are any differences in eating habits between girls and boys.

Material and methods. The study was conducted among 337 post-primary school students, including 126 girls and 211 boys. A standardised questionnaire "My eating habits" was used as a research tool.

Results. Secret snacking was slightly more common among girls $(27.78 \%)$ than boys (24.17\%). It was also girls who mostly admitted that other people comment on their diet, as indicated by $33.33 \%$ of girls and $18.96 \%$ of boys. Girls are also more likely to be dissatisfied with their body weight (41.27\% vs. $27.49 \%)$ and to occasionally avoid eating despite feeling hungry (42.06\% vs. $27.01 \%)$ compared to boys.

Conclusions. The eating habits of young people are mostly varied. There are differences in the dietary habits of girls and boys; girls are more likely than boys to overeat under the influence of emotions and to apply dietary restrictions to themselves. In order to promote healthy eating habits and support the mental well-being of young people, it is recommended to provide nutritional education and to implement psychological support for those in need.
\end{abstract}

Key words: eating habits, eating disorders, dietary restrictions, adolescents

\section{STRESZCZENIE}

Wprowadzenie. Kształtowanie zwyczajów żywieniowych zachodzi głównie w pierwszych etapach życia człowieka. Nieprawidłowości odżywiania u osób młodych w przyszłości mogą prowadzić do zaburzeń odżywiania oraz predysponować do nieprawidłowej masy ciała.

Cel badań. Celem badania było poznanie zwyczajów żywieniowych młodzieży oraz stwierdzenie czy istnieją różnice pomiędzy zwyczajami żywieniowymi dziewcząt i chłopców

Material i metody. Badanie zostało przeprowadzone wśród 337 uczniów szkoły ponadpodstawowej, w tym wśród 126 dziewcząt oraz 211 chłopców. Narzędziem badawczym był standaryzowany kwestionariusz ankiety „Moje Zwyczaje Żywieniowe".

Wyniki. Nieznacznie większe skłonności do podjadania w tajemnicy przed innymi wykazują dziewczęta (27,78\%), niż chłopcy (24,17\%). To dziewczęta w przewadze przyznają, że inni ludzie komentują ich sposób odżywiania, na taką odpowiedź wskazało 33,33\% dziewcząti 18,96\% chłopców. Dziewczęta także częściej, niż chłopcy wykazują niezadowolenie ze swojej masy ciała (odpowiednio 41,27\% i 27,49\% z nich) oraz pomimo odczuwania głodu unikają czasami jedzenia $(42,06 \%$ i $27,01 \%)$

Wnioski. Zwyczaje żywieniowe młodzieży są w większości zróżnicowane. Istnieją różnice w zwyczajach żywieniowych dziewcząt i chłopców; dziewczęta w porównaniu do chłopców wykazują większe skłonności do przejadania się pod wpływem emocji oraz do stosowania względem siebie restrykcji dietetycznych. W celu promowania prawidłowych zwyczajów żywieniowych oraz wspierania dobrej kondycji psychicznej młodzieży zaleca się prowadzenie edukacji żywieniowej oraz wdrożenie pomocy psychologicznej dla osób jej potrzebujących.

Słowa kluczowe: zwyczaje żywieniowe, zaburzenia odżywiania, restrykcje dietetyczne. młodziéz

Corresponding author: Elżbieta Szczepańska, Department of Human Nutrition, School of Health Sciences in Bytom, Medical University of Silesia; Jordana 19 Street, 41-808 Zabrze, Poland, Phone: +48 32 275-51-97; e-mail: eszczepanska@sum.edu.pl 


\section{INTRODUCTION}

Eating habits are mainly shaped at the first stages of human life [4]. We enter adulthood with an already developed system of eating habits. Therefore, monitoring and correction of poor eating habits among young individuals is needed as they may lead to future eating disorders and predispose to abnormal body weight [1].

Eating disorders are significantly more common in women than in men, and usually manifest in late adolescence or early adulthood. Fear of excess calories may lead to dietary restrictions, such as intentional limitation of food intake or skipping meals [13]. Common unawareness of eating disorders, such as for example anorexia and bulimia, may result in a failure to initiate appropriate treatment and, consequently, the development of chronic diseases [9, 21]. Eating disorders not necessarily lead to weight loss. Increased calorie intake due to eating disorders causes excess fat accumulation and, consequently, overweight and obesity [18]. This problem is currently seen in most European countries, posing one of major public health issues [24]. Excess body weight predisposes to multiple diet-related diseases, such as cardiovascular diseases, diabetes mellitus, and cancer. Therefore, maintenance of normal body mass index (BMI) is strongly recommended [11, 25]. Prevention of overweight and obesity is primarily based on education and promotion of healthy lifestyle. Educational programmes should inform about, among other thing, its consequences, whereas prevention should provide guidance on changes in eating habits and physical activity [2].

Eating disorders and increased body weight may also be of psychological aetiology. Emotional eating involves consuming meals depending on mental state. In this type of disorders, dietary restrictions involving reduced intake of dietary calories should be preceded by psychological therapy to support emotional stability [26].

Habitual overeating, emotional eating, and dietary restrictions are risk factors for eating disorders. The measurement of the above factors allows for the diagnosis of the problem among selected groups of society, followed by implementation of preventive and educational measures [16]. Preventing bad eating habits, promoting the Pyramid of Healthy Eating and physical activity may help introduce eating habits that support health and good mental wellbeing [3, 4, 20].

The aim of this study was to investigate eating habits among adolescents and verify whether there are any differences in eating habits between girls and boys.

\section{MATERIALS AND METHODS}

The study was conducted in the first quarter of 2020 among 337 post-primary school students from the Silesia Province, including 126 girls and 211 boys. The study was approved by the school principal.

A standardised questionnaire "My Eating Habits" by Ogińska-Bulik and Putyński [16] was used as a research tool. The questionnaire includes 30 yes/ no questions. The questions were classified into three categories related to emotional overeating, habitual overeating and dietary restrictions. Each "yes" answer was scored 1 (except for 5 appropriately marked questions). The total score was used to calculate the mean and standard deviation for each category for all respondents and separately for sex groups. The answers were collected and analysed using Microsoft Excel 2010 spreadsheet software. Statistica 13 software was used to calculate mean, standard deviation, and for statistical analysis. Correlations between sex and different eating habits were verified using the Chi-squared test. A p-value $<0.05$ was considered statistically significant for all analyses.

\section{RESULTS}

Means and standard deviations for factors in the groups are shown in Table 1. The mean value of answers to questions on habitual overeating was similar for girls and boys, i.e. 3.72 and 3.75, respectively. There were differences in the mean values of answers to questions on emotional overeating and dietary restrictions (4.07 and $3.09 ; 3.84$ and 3.04 , respectively). The highest standard deviation for all respondents was reported for the group of questions on habitual overeating, whereas the lowest standard deviation was reported for the group of questions on dietary restrictions, i.e. 2.49 and 2.15 , respectively.

Table 1. Mean values of answers to questions on habitual overeating, emotional overeating and dietary restrictions for girls and boys

\begin{tabular}{|c|c|c|c|c|c|c|}
\hline \multirow{2}{*}{ Factor } & \multicolumn{2}{|c|}{ Total } & \multicolumn{2}{c|}{ Girls } & \multicolumn{2}{c|}{ Boys } \\
\cline { 2 - 7 } & Mean & SD & Mean & SD & Mean & SD \\
\hline $\begin{array}{c}\text { Habitual } \\
\text { overeating }\end{array}$ & 3.74 & 2.49 & 3.72 & 3.74 & 3.75 & 2.40 \\
\hline $\begin{array}{c}\text { Emotional } \\
\text { overeating }\end{array}$ & 3.46 & 2.23 & 4.07 & 2.23 & 3.09 & 2.15 \\
\hline $\begin{array}{c}\text { Dietary } \\
\text { restrictions }\end{array}$ & 3.34 & 2.15 & 3.84 & 2.16 & 3.04 & 2.08 \\
\hline
\end{tabular}

The study showed that $24.60 \%$ of girls and $24.64 \%$ of boys attach too much importance to food, with $59.52 \%$ and $64.93 \%$ of them, respectively, considering 
food to be an important part of their lives. However, uninhibited eating is more common among boys than girls, with such tendencies reported by $40.28 \%$ and $30.16 \%$ of them, respectively. Girls, on the other hand, are slightly more prone to snacking in secret than boys $(27.78 \%$ vs. $24.17 \%)$. A total of $27.16 \%$ of respondents, including $30.16 \%$ of girls and $26.07 \%$ of boys, admitted to eating despite satiety; $75.88 \%$ of respondents $(77.77 \%$ of girls and $65.40 \%$ of boys) rarely overeat (Table 2).

In the part of the questionnaire on emotional overeating, the responses of the two groups differed (Table 3). Overeating anxiety was significantly more common in girls than boys ( $41.27 \%$ vs. $16.11 \%)$. The urge to dispose of unnecessary calories after having a large meal was also more common among girls (50\%) than boys (37.44\%). Half (50\%) of students, including $65.87 \%$ of girls and $41.23 \%$ of boys, would like to weigh less than they do. Only $19.29 \%$ of students, including $22.22 \%$ of girls and $17.54 \%$ of boys, admitted that they start eating meals when they get upset, and $64.69 \%$ of all students, including $59.52 \%$ of girls and $67.77 \%$ of boys, reported eating as a way to improve mood.

The part of the questionnaire on dietary restrictions (Table 4) also revealed some differences. A total of $46.83 \%$ of girls and $64.45 \%$ of boys are rarely concerned about their body weight, and dissatisfaction with one's figure was reported by $67.46 \%$ and $40.28 \%$ of them, respectively. Girls are also more likely than boys to show dissatisfaction with their body weight (41.27\% and 27.49\%, respectively) and sometimes avoid meals despite feeling hungry $(42.06 \%$ and

Table 2. Answers to questions on habitual overeating for girls and boys

\begin{tabular}{|l|c|c|c|c|c|c|}
\hline \multirow{2}{*}{ Answers to questions } & \multicolumn{3}{c|}{ Habitual overeating } \\
\cline { 2 - 7 } & \multicolumn{2}{|c|}{ Total } & \multicolumn{2}{c|}{ Girls } & \multicolumn{2}{c|}{ Boys } \\
\cline { 2 - 7 } & $\mathrm{n}=337$ & $\%$ & $\mathrm{n}=126$ & $\%$ & $\mathrm{n}=211$ & \multicolumn{1}{c|}{$\%$} \\
\hline I often think about eating & 203 & 60.24 & 73 & 57.94 & 130 & 61.61 \\
\hline Eating is an important part of my life & 212 & 62.91 & 75 & 59.52 & 137 & 64.93 \\
\hline Sometimes I snack in secret from others & 86 & 25.52 & 35 & 27.78 & 51 & 24.17 \\
\hline I eat often, even when I feel full & 93 & 27.16 & 38 & 30.16 & 55 & 26.07 \\
\hline I rarely overeat *) & 115 & 34.12 & 42 & 33.33 & 73 & 34.60 \\
\hline I eat often, although I am not hungry & 132 & 39.17 & 55 & 43.65 & 77 & 36.49 \\
\hline Sometimes I eat uninhibited & 123 & 36.50 & 38 & 30.16 & 85 & 40.28 \\
\hline I rarely feel overeaten *) & 131 & 38.87 & 54 & 42.86 & 77 & 36.49 \\
\hline Food is too important to me & 83 & 24.63 & 31 & 24.60 & 52 & 24.64 \\
\hline My stomach is like a bottomless sack & 82 & 24.63 & 28 & 22.22 & 55 & 26.07 \\
\hline
\end{tabular}

*) The question is scored for "NO" answer

Table 3. Answers to questions on emotional overeating for girls and boys

\begin{tabular}{|c|c|c|c|c|c|c|c|}
\hline \multirow{3}{*}{ Answers to questions } & \multicolumn{7}{|c|}{ Emotional overeating } \\
\hline & \multicolumn{2}{|c|}{ Total } & \multicolumn{2}{|c|}{ Girls } & \multicolumn{2}{|c|}{ Boys } & \multirow{2}{*}{$\mathrm{p}$-value } \\
\hline & $\mathrm{n}=337$ & $\%$ & $\mathrm{n}=126$ & $\%$ & $\mathrm{n}=211$ & $\%$ & \\
\hline I often feel anxious when I eat too much & 86 & 25.52 & 52 & 41.27 & 34 & 16.11 & 0.00 \\
\hline Other people comment on my diet & 82 & 24.33 & 42 & 33.33 & 40 & 18.96 & 0.00 \\
\hline $\begin{array}{l}\text { I eat more than normal when I am anxious } \\
\text { or upset }\end{array}$ & 68 & 20.18 & 31 & 24.60 & 37 & 17.54 & $>0.05$ \\
\hline $\begin{array}{l}\text { Sometimes when I start to eat, I feel that I } \\
\text { won't be able to tell myself "enough" }\end{array}$ & 69 & 20.47 & 27 & 21.43 & 42 & 19.91 & $>0.05$ \\
\hline I would prefer to weigh less than I do now & 170 & 50.45 & 83 & 65.87 & 87 & 41.23 & 0.00 \\
\hline My diet generally depends on my mood & 162 & 48.07 & 72 & 57.14 & 90 & 42.65 & 0.01 \\
\hline $\begin{array}{l}\text { In the company, I eat medium but ,allow” } \\
\text { myself more when I am alone }\end{array}$ & 104 & 30.86 & 40 & 31.75 & 64 & 30.33 & $>0.05$ \\
\hline When I get angry, I start eating & 65 & 19.29 & 28 & 22.22 & 37 & 17.54 & $>0.05$ \\
\hline $\begin{array}{l}\text { I would like to get rid of unnecessary } \\
\text { calories after having a large meal }\end{array}$ & 142 & 42.14 & 63 & 50.00 & 79 & 37.44 & 0.02 \\
\hline Food puts me in a good mood & 218 & 64.69 & 75 & 59.52 & 143 & 67.77 & $>0.05$ \\
\hline
\end{tabular}


Table 4. Answers to questions on dietary restrictions for girls and boys

\begin{tabular}{|c|c|c|c|c|c|c|c|}
\hline \multirow{3}{*}{ Answers to questions } & \multicolumn{6}{|c|}{ Dietary restrictions } & \multirow{3}{*}{$\mathrm{p}$-value } \\
\hline & \multicolumn{2}{|c|}{ Total } & \multicolumn{2}{|c|}{ Girls } & \multicolumn{2}{|c|}{ Boys } & \\
\hline & $\mathrm{n}=337$ & $\%$ & $\mathrm{n}=126$ & $\%$ & $\mathrm{n}=211$ & $\%$ & \\
\hline I rarely follow diets $*)$ & 86 & 25.52 & 27 & 21.43 & 59 & 27.96 & $>0,05$ \\
\hline $\begin{array}{l}\text { I read and collect diets from magazines and } \\
\text { books }\end{array}$ & 41 & 12.17 & 16 & 12.70 & 25 & 11.85 & $>0.05$ \\
\hline I rarely worry about my weight $*$ ) & 142 & 42.14 & 67 & 53.17 & 75 & 35.55 & 0.00 \\
\hline I am not satisfied with my figure & 170 & 50.45 & 85 & 67.46 & 85 & 40.28 & 0.00 \\
\hline $\begin{array}{l}\text { Sometimes I avoid eating, even when I'm } \\
\text { hungry }\end{array}$ & 110 & 32.64 & 53 & 42.06 & 57 & 27.01 & 0.00 \\
\hline I put too much weight on my body weight & 110 & 32.64 & 52 & 41.27 & 58 & 27.49 & 0.01 \\
\hline I rarely feel guilty after overeating * & 190 & 56.38 & 73 & 57.94 & 117 & 55.45 & $>0.05$ \\
\hline I like to feel empty in my stomach & 51 & 15.13 & 24 & 19.05 & 27 & 12.80 & $>0.05$ \\
\hline I often follow diets & 64 & 18.99 & 20 & 15.87 & 44 & 20.85 & $>0.05$ \\
\hline I consciously limit my food consumption & 161 & 47.77 & 67 & 53.17 & 94 & 44.55 & $>0.05$ \\
\hline
\end{tabular}

*) The question is scored for "NO" answer

$27.01 \%$ ). A total of $18.99 \%$ of all respondents, including $15.87 \%$ of girls and $20.85 \%$ of boys, often use diets; $15.13 \%$ (19.05\% and $12.80 \%$, respectively) of respondents like the empty stomach feeling; and $45.62 \%$ (42.06\% and $44.55 \%$, respectively) rarely feel guilty after overeating.

\section{DISCUSSION}

The study showed that habitual overeating behaviours dominated in the group of students $(\mathrm{M}=$ 3.74), whereas dietary restrictions were less common $(\mathrm{M}=3.34)$. Similar findings were presented by Kobos et al. [8] with behaviours associated with habitual overeating and dietary restrictions declared by $\mathrm{M}$ $=3.66$ and $\mathrm{M}=3.59$ secondary school students. As reported by the authors, emotional overeating was more common compared to our study $(\mathrm{M}=4.84$ and $\mathrm{M}$ $=3.46$, respectively). Different results compared to our study were obtained by Ogińska-Bulik and Putyński [16] with dominant emotional overeating $(\mathrm{M}=4.67)$, and less common habitual overeating $(\mathrm{M}=2.94)$.

Analysis of our findings showed that $60.24 \%$ of students participating in the study often think about food. Similar results were obtained by Porwolik et al. [22] who assessed the impact of the place of birth and upbringing on eating habits among 267 students of Medical Faculty of Wroclaw Medical University. The authors showed that $66.3 \%$ of students often think about food. They also showed that 20.8\% of respondents practised secret snacking. This is comparable to our findings (25.52\%). Our respondents were also asked about the importance of food in their life, with $24.63 \%$ of them admitting that they attach too much importance to food.
Different findings were presented by Sekuła et al. [23] with $56.8 \%$ of respondents reporting that they attach too much importance to food. These differences may have resulted from the choice of sample as the study enrolled individuals with obesity, as well as from the type of questionnaire used by the authors. The study showed that $39.17 \%$ of students eat despite not being hungry. A significant difference was found in the frequency of affirmative answers provided by girls and boys (43.65\% vs. $36.49 \%)$. Similar results were obtained by Porwolik et al. [22] with such answer provided by $37.6 \%$ of students.

A total of $24.63 \%$ of respondents agreed with the statement "my stomach is like a bottomless pit". Different findings were presented by Sekuta et al. [23], with the above mentioned statement confirmed by $62.2 \%$ of respondents. It should be noted, however, that this question was addressed to obese patients in the cited article, which could have influenced the obtained results. No reduction in ghrelin levels occurs after food intake in obese individuals, which results in persistent hunger [6].

Our study showed that $62.91 \%$ of students considered eating to be an important part of life. A higher percentage was reported by Sekuła et al. [23], with $70.3 \%$ of respondents indicating this answer, whereas Porwolik et al. [ 22] showed that $35.3 \%$ of respondents attach too much importance to food. On the other hand, $27.16 \%$ of students agreed with the statement "I eat often, even when I already feel full". Similar findings were presented by Porwolik et al. [22], while different results were obtained by Sekuła et al. [23]

In the present study, the students were also asked questions on the frequency of overeating and the resulting feeling of guilt. Our study showed that $34.12 \%$ 
of respondents often overeat, and $56.38 \%$ of them feel guilty about it. Furthermore, $61.13 \%$ of respondents claimed that they rarely feel extremely full. Similar results were obtained by Porwolik et al. [22], who showed that $30.6 \%$ of students admitted that they often overeat, and $69.4 \%$ reported that they rarely feel extremely full. More affirmative answers in relation to overeating were obtained by Sekuła et al. [23] with $56.8 \%$ of respondents declaring frequent overeating, and $51.4 \%$ of respondents feeling guilty about it. Both overeating and dietary restrictions are influenced by different emotions. Many studies have shown that increased appetite, which leads to an increased intake of food, is primarily caused by experiencing negative emotions [15, 17, 27].

The obtained results showed that $36.50 \%$ of students occasionally overeat. By contrast, Sekuła et al. showed that this fact was confirmed by $59.50 \%$ of respondents [23]. As demonstrated by other authors, situations such as social gatherings or activities involving attention, such as watching TV, cause loss of control over eating. As a result, there is a reduction in self-awareness, when the person pays no attention to the quality or quantity of food consumed [15].

In our study, $24.33 \%$ of students reported that others comment on their diet. This was also confirmed by $54.1 \%$ of respondents in the study by Sekuta et al. [23]. Everyone has an influence on how they look, but is at the same time subject to pressure and comparisons with common body standards. Overweight and obesity are often viewed negatively by society [10].

The statement "when I feel anxious or upset, I eat more than I normally do" was confirmed by $20.18 \%$ of students. Additionally, $19.29 \%$ of students admitted that they start to eat after getting upset. Both of these phenomena were more common in the study by Porwolik et al., with $36.4 \%$ and $31.2 \%$ of students confirming such statements [22]. Sekuła et al. showed in their study that $56.8 \%$ of respondents eat more than they normally do when feeling anxious, and that they start eating after getting upset [23]. Psychological stress is one of the factors that contribute to obesity and overweight. Furthermore, confusing emotions with feeling hungry often leads to higher food intake [7].

It is disturbing that $50.45 \%$ of study participants declared dissatisfaction with their body and would like to weigh less than they do. Similar findings were obtained by Porwolik et al. [22], who showed that $53.8 \%$ of students would also like to weigh less than they do, whereas up to $74 \%$ of respondents confirmed this fact in a study by Kobos et al. [8]. Criticism of one's own figure was more common among girls than boys $(67.46 \%$ vs. $40.28 \%)$. Dissatisfaction with one's body among girls may be due to the image created by the media, with a slim woman considered to be a canon of beauty. Materna et al. [12], who assessed the awareness of middle school girls about bulimia and anorexia, showed that $48 \%$ of them wished they had a figure of a fashion model and that $75 \%$ of them do not tolerate their own body.

In our study, $48.07 \%$ of students declared that their eating habits generally depended on their mood and, additionally, $64.69 \%$ of them confirmed that eating improves their mood. Different findings were presented by Sekula et al. [23], with $70.3 \%$ of respondents admitting that their eating habits depend on their mood, and $67.6 \%$ of them declaring that eating improves their mood [23]. However, this question was addressed to patients with morbid obesity in the cited study. Individuals suffering from this condition often have a tendency to over-experience emotions, which, in addition to a tendency to impulsive behaviour, can have a significant impact on eating habits depending on $\operatorname{mood}[19]$.

The statement "I eat moderately in the company of others, but I allow myself for more when alone" was confirmed by $30.86 \%$ of our respondents. Such declaration was made by $21.41 \%$ of respondents in the study by Porwolik et al. [22] and 59.5\% in the study by Sekuta et al. [23]

Our study showed that $32.64 \%$ of students avoid food despite feeling hungry and $47.77 \%$ of respondents deliberately use dietary restrictions. A higher percentage of affirmative answers (59.5\%) regarding limited food intake despite hunger and a similar percentage $(43.2 \%)$ for the question on intentional dietary restrictions were reported by Sekuła et al. [23].

Niewierska et al. [14], who conducted their study among secondary-school students, reported that $26 \%$ of girls and $12 \%$ of boys declared the use of slimming diets. These results differ from our findings, according to which boys were more likely to use diets $(20.85 \%$ vs. $15.87 \%$ ). Alarming data were also presented by Jodkowska [5], who assessed the use of slimming diets among boys and girls aged 11-15 years. The author showed that up to $35.8 \%$ of girls and $14.3 \%$ of boys used slimming diets. In the context of dieting among girls, these results are twice higher compared to our study. It should be noted, however, that our questionnaire did not specify the type of diet used, which may have contributed to these differences.

Incorrect eating habits are one of the causes of diet-related diseases $[8,9]$. Similarly to other authors, our findings point to issues that need to be considered when shaping correct eating habits.

\section{CONCLUSIONS}

Eating habits of adolescents are mostly varied.

There are some differences in eating habits between boys and girls, with the latter more prone to emotional overeating and more likely to use dietary restrictions. 
Nutritional education and, if needed, psychological help are recommended to promote healthy eating habits and support good mental health in adolescents.

\section{Conflict of interest}

None declared.

\section{REFERENCES}

1. Decyk-Chęcel A.: Zwyczaje żywieniowe dzieci i młodzieży [Children's and adolescents' eating habits]. Probl Hig Epidemiol 2017;98(2):103-109 (in Polish).

2. Drewa A., Zorena K.: Profilaktyka nadwagi i otyłości u dzieci i młodzieży w krajach europejskich [Prevention of overweight and obesity in children and adolescents in European countries]. Pediatr Endocrinol Diabetes Metab 2017;23(3):152-158 doi:10.18544/PEDM23.03.0087 (in Polish).

3. Godos J., Currenti W., Angelino D., Mena P., Castellano S., Caraci F., Galvano F., Del Rio D., Ferri R., Grosso G.: Diet and Mental Health: Review of the Recent Updates on Molecular Mechanisms. Antioxidants (Basel) 2020; 9(4):346 doi:10.3390/antiox9040346.

4. Jarosz M., Wolnicka K., Sajór I.: Zalecenia dotyczące żywienia i aktywności fizycznej [Recommendations on nutrition and physical activity]. In: Jarosz M. Normy żywienia dla populacji Polski [Nutrition standards for the Polish population]. Warszawa, Instytut Żywności i Żywienia 2017:261-262 (in Polish).

5. Jodkowska M. Stosowanie diet odchudzających [Applying a slimming diet]. Instytut Matki i Dziecka. Warszawa 2015;163-168.

6. Kłósek P.: Rola stresu psychologicznego $\mathrm{w}$ neuroendokrynnej regulacji pobierania pokarmu i powstawaniu otyłości [The role of psychological stress in neuroendocrine regulation of food intake and obesity]. Forum Zaburzeń Metabol 2016;7(3):111-118 (in Polish).

7. Klósek P.: Zależności między stresem psychologicznym a powstawaniem otyłości [Relationships between psychological stress and obesity]. Forum Med Rodz 2016;10(3),145-152 (in Polish).

8. Kobos E., Kubiak A., Knoff B., Czarnecka J.: Zwyczaje żywieniowe uczennic klas trzecich szkół gimnazjalnych i liceów ogólnokształcących [Eating habits of thirdgrade students of lower secondary and general secondary schools]. Piel Pol 2016;2(60):220-226 (in Polish).

9. Kotwas A., Karakiewicz-Krawczyk K., Zabielska P, Jurczak A., Bażydto M., Karakiewicz B.: Występowanie zaburzeń odżywiania wśród uczennic szkół ponadgimnazjalnych [Occurrence of eating disorders among students of upper secondary schools]. Psychiatr Pol 2020;54(2):253-263.

10. Krogulec M.: Postrzeganie osób z nadmierną masą ciała przez ludzi młodych [The perception of people with excess body weight by young people]. Władza Sądzenia 2015;7,137-149. Available http://wladzasadzenia.pl/ nr/7-2015/ (Accessed 06.07.2020).
11. Lahey $R$, Khan SS.: Trends in Obesity and Risk of Cardiovascular Disease. Curr Epidemiol Rep 2018;5(3):243-251. doi:10.1007/s40471-018-0160-1.

12.Materna J., Mańdziuk M., Sitarz L., Kaszuba B.: Świadomość dziewcząt $\mathrm{w}$ wieku gimnazjalnym na temat bulimii i anoreksji [Awareness of middle-school girls about bulimia and anorexia]. In: Naćkowia J., Leśny J: Badania i rozwój młodych naukowców w Polsce [Research and development of young scientists in Poland]. Poznań, Wydawnictwo Młodzi Naukowcy, 2018.

13. Nelkowska D.: Arthorexia nervosa: definicje, kryteria, klasyfikacje -kontrowersje i rozbieżności w wynikach badań [Orthorexia nervosa: definitions, criteria, classifications - controversies and discrepancies in research results]. Annales Universitatis Mariae CurieSkłodowska Lublin-Polonia 2019;32(3):169-180 (in Polish).

14. Niewierska A., Sowada A., Silarska D., Różańska $D .:$ Ocena poziomu wiedzy na temat żywienia oraz wybranych elementów stylu życia uczniów szkół ponadgimnazjalnych [Assessment of the level of knowledge about nutrition and selected elements of lifestyle of high school students]. Piel Zdr Publ 2016;6(4):267-273 (in Polish).

15. Ogińska-Bulik N.: Pułapki jedzenia [Food traps]. Style i Charaktery 2007;2:15-18 (in Polish).

16. Ogińska-Bulik N., Putyński L.: Kwestionariusz Moje Zwyczaje Żywieniowe - konstrukcja i właściwości psychometryczne [My Nutritional Habits questionnaire - structure and psychometric properties]. Acta Universitatis Lodziensis Folia Psychologica 2000;4:2533 (in Polish).

17. Ogińska-Bulik N.: Psychologia nadmiernego jedzenia [The psychology of excessive eating]. Łódź, Wydawnictwo Uniwersytetu Łódzkiego, 2004.

18. Okreglicka K., Skibniewska M., Kozlowska A., Jagielska A.: Nadwaga, otyłość a dieta niskoenergetyczna w praktyce lekarza internisty [Overweight, obesity and a low-energy diet in the practice of an internist]. Żyw Człow Metab 2016;43(4):281-295 (in Polish).

19. O'Neil M.P., Jarrel P.M.: Psychological aspects of obesity and very low-calorie diets. Am J Clin Nutr 1992;56:185-189.

20. Owen L, Corfe B.: The role of diet and nutrition on mental health and wellbeing. Proc Nutr Soc 2017;76(4):425-426 doi:10.1017/S0029665117001057.

21. Pałasz A., Rojczyk E., Siwiec A., Janas-Kozik M.: Nesfatyna-1 w neurochemii zaburzeń odżywiania [Nesfatin-1 in the neurochemistry of eating disorders] Psychiatr Pol 2020;54(2):209-222 (in Polish).

22.Porwolik M, Porwolik K, Domagała Z. Ocena związku środowiska studentów $\mathrm{z}$ ich nawykami żywieniowymi [Assessment of the relationship between the students' environment and their eating habits]. In: Turkowski $K .:$ Zdrowie i jego uwarunkowania [Health and its determinants]. Lublin, Wydawnictwo Naukowe NeuroCentrum, 2017.

23.Sekuła M., Boniecka I., Paśnik K.: Ocena zachowań zdrowotnych, żywieniowych i poczucia własnej skuteczności chorych z otyłością olbrzymią [Assessment 
of health behaviors, nutritional behaviors, and selfefficacy in patients with morbid obesity]. Psychiatr Pol 2019;53(5):1125-1137 (in Polish).

24.Spinelli A. , Buoncristiano M., Kovacs V., Yngve A., Spiroski I., Obreja G.: Prevalence of Severe Obesity Among Primary School Children in 21 European Countries Obes Facts. 2019;12(2):244-258.

25. The GBD 2015 Obesity Collaborators: Health Effects of Overweight and Obesity in 195 Countries over 25 Years. N Engl J Med 2017;377(1):13-27, doi: 10.1056/ NEJMoa1614362. Epub 2017 Jun 12. 26.van Strien T:: Causes of Emotional Eating and Matched Treatment of Obesity. Curr Diab Rep. 2018;18(6):35. doi:10.1007/s11892-018-1000-x.

27. Zubrzycka E.: Schudnąć bez diety. Mity na temat nadwagi [Lose weight without dieting. Myths about being overweight]. Gdańsk, Gdańskie Wydawnictwo Psychologiczne, 2011.

Received: 10.08 .2020

Accepted: 04.11.2020 